\title{
BACK TO ABC AFTER XYZ: SHOULD WE BE CONCERNED ABOUT 'INTERNATIONAL CONCERN'?
}

\author{
Sarah Murray*
}

\begin{abstract}
MR BURMESTER: Your Honour, I hope to say little on international concern because there are all these other aspects of external affairs.

HAYNE J: It is just starting to look worried, very international. ${ }^{1}$
\end{abstract}

The recent High Court decision of $X Y Z$ v Commonwealth ('XYZ') ${ }^{2}$ has strengthened the aura of uncertainty surrounding the concept of 'international concern' and its role in widening the application of $\mathbf{s} 51$ (xxix) of the Commonwealth Constitution. This article considers the $X Y Z$ decision in light of past judicial exegesis and addresses what may lie ahead for this aspect of the external affairs power.

'International concern' has, for some years, hovered as a possible basis for the subject matter of legislation to attract the Commonwealth external affairs power, alongside other grounds such as the implementation of an international convention or recommendation, geographical externality, relations with other countries or customary international law. The head of power relies upon such grounds to colour a piece of Commonwealth legislation with the hue of 'external affairs'. This 'colouring' therefore enables a subject matter to be within the Commonwealth Parliament's legislative competence.

\section{THE FACTS OF XYZ}

The $X Y Z$ case arose in the context of child sex tourism charges laid against the plaintiff under Part IIIA of the Crimes Act 1914 (Cth). ${ }^{3}$ The plaintiff was an Australian citizen and was alleged to have committed offences in Thailand in 2001. The legislation operated extraterritorially, targeting sex offences committed by Australian citizens or residents 'while outside Australia' against a person under 16 years of age. However, as the facts themselves demonstrated, the victim of such offences did not have to be Australian.

* Sarah Murray is a Lecturer at the University of Western Australia where she teaches Constitutional Law. The author is indebted to Dr Peter Johnston for his invaluable recommendations on an early draft of this paper.

1 Transcript of Proceedings, Thomas $v$ Mowbray (High Court of Australia, 21 February 2007). (2006) 227 ALR 495.

The offences had been included in the Crimes Act 1914 (Cth) following amendments made by the Crimes (Child Sex Tourism) Amendment Act 1994 (Cth). 
The High Court was asked to consider whether either s $50 \mathrm{BA}^{4}$ or s $50 \mathrm{BC}^{5}$ of the Crimes Act 1914 (Cth) ('the relevant provisions') were within the scope of s 51(xxix) of the Commonwealth Constitution. A majority of the High Court found that the provisions were constitutionally valid and within the external affairs power, with Callinan and Heydon JJ jointly dissenting.

The case considered a number of aspects of the external affairs power, with much consideration given to the scope of the geographical externality concept which the majority accepted as validating the legislation. ${ }^{6}$ This article intends to focus upon the discussion of 'international concern' as a touchstone for the external affairs power and the question mark which clings to this concept.

\section{HOW THE XYZ COOKIE CRUMBLED}

Amongst other arguments, the Commonwealth submitted that the prevention of abuse and exploitation of children amounted to a matter of 'international concern' and brought the relevant provisions within the scope of the external affairs power. This characterisation was said to be supported by a number of international endeavours, including the adoption of the Convention on the Rights of the Child by the United Nations in 1989, ${ }^{7}$ the accompanying Optional Protocol in May 2000, ${ }^{8}$ the appointment of a Special Rapporteur on the Sale of Children, Child Prostitution and Child Pornography as well as the existence of legislation in over 30 countries worldwide targeting inappropriate sexual behaviour committed extraterritorially. It was therefore argued that the relevant provisions dealt with a subject matter that was sufficiently 'relevant to Australia's relationships with other nation states, and with relevant international organisations', to be of 'international concern'. 9

As the majority of the Court accepted the Commonwealth's submissions that the relevant provisions were supported by other aspects of the external affairs power (namely, geographical externality) its submissions in relation to 'international concern' did not have to be conclusively addressed. However, several comments were made by the Court in relation to the latter 'unsettled' ${ }^{10}$ principle.

One common theme expressed by the bench was a sense of trepidation regarding the limitless subject matter that could fit under the expanding 'international concern' umbrella. ${ }^{11}$ Gleeson CJ indicated that the concept of 'international concern' had the potential to push Australia's legislative capacity beyond Australia's assumed obligations, but that it was questionable whether the raising of an issue at an

4 Section 50BA(1) 'A person must not, while outside Australia, engage in sexual intercourse with a person who is under 16 '.

5 Section 50BC targeted offences committed outside Australia relating to acts of indecency involving a person under 16 or engaging in sexual intercourse in the presence of a person under 16.

6 See Anne Twomey, 'Geographical Externality and Extraterritoriality: $X Y Z v$ Commonwealth' (2006) 17 Public Law Review 253, 256.

7 Opened for signature 20 November 1989, 1577 UNTS 44 (entered into force 2 September 1990).

8 Opened for signature 25 May 2000, 2171 UNTS 247 (entered into force 12 February 2002).

$9 \quad$ XYZ (2006) 227 ALR 495, 513 [63] (Kirby J); see also 556 [214] (Callinan \& Heydon JJ).

10 Ibid 511 [53] (Gummow, Hayne and Crennan JJ).

11 Ibid 502 [18] (Gleeson CJ). 
international forum could, on its own, cast a subject as being of 'international concern' ${ }^{12}$ Kirby J reflected that there was a risk that it could encompass a 'diverse multitude of topics lacking any precise definition or meaning' 13 His Honour referred to the plaintiff's contention that an expression as broad as 'international concern' would fail to provide an adequate litmus test for Commonwealth legislation and that the phrase would need to be narrowed by words such as "'real", "genuine", "widespread", "pressing", "established", or "undisputed". 14 Alternatively, the plaintiff referred to the need for qualifications such as the existence of a 'nexus between Australia and the supposed subject of external affairs' or the inclusion of a proportionality requirement. ${ }^{15}$ The joint judgment of Gummow, Hayne and Crennan JJ referred briefly to the concept and its role in Commonzealth $v$ Tasmania ${ }^{16}$ and Polyukhovich $v$ Commonwealth ${ }^{17}$ but determined that the case did not require that the unresolved aspects of 'international concern' be addressed. ${ }^{18}$

The dissenting judgment of Callinan and Heydon JJ asserted that there was no established authority for the concept of 'international concern' and that the existing insubstantial obiter dicta fell short of establishing concrete boundaries for the phrase. ${ }^{19}$ Their Honours referred to the Federal Court decision of Soulitopoulos $v$ La Trobe University Liberal $\mathrm{Club}^{20}$ as an example of the potential unworkability of the concept because the constitutional validity of legislation might vary depending on the status of the relevant subject matter in the international sphere at a particular point in time. ${ }^{21}$

Their Honours stated that its 'volatility' and 'elusiveness' 'strongly suggest that the international concern doctrine does not exist; for if it did, it would operate antithetically to the rule of law. ${ }^{22}$ Especially problematic was how the existence of sufficient 'concern' within the international community could be established, ${ }^{23}$ particularly, in the context of the 'fuzzy' zone where there is no treaty negotiated on the matter. ${ }^{24}$ What could be said to render a particular subject of 'international concern' when the 'opinions of national governments' and citizens vary? ${ }^{25}$ Callinan and Heydon JJ pondered what workable boundaries could be adopted to avoid the Commonwealth Parliament obtaining carte blanche through the means of a 'plenary' interpretation. ${ }^{26}$ They emphasised the difficulty of introducing a proportionality cap, when, in contradistinction to international conventions, there would not be much substance from which to draw the 'appropriate and adapted' boundary. ${ }^{27}$ They even noted that a

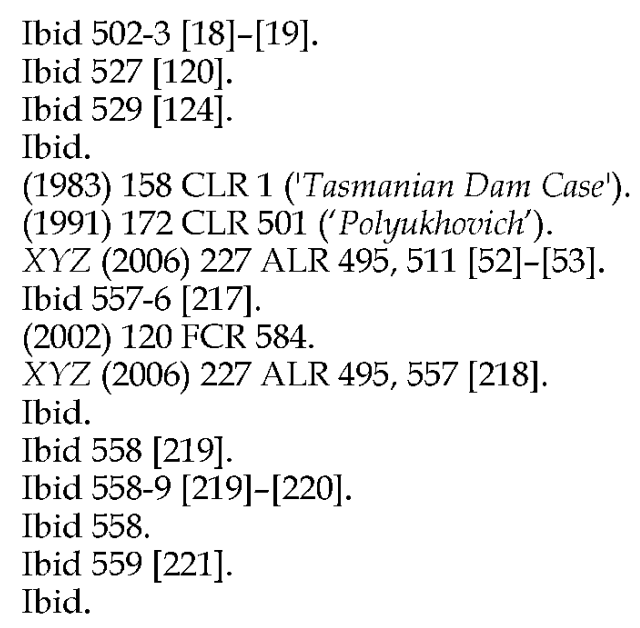


wide application of 'international concern' could have resulted in the opposite result in Australian Communist Party $v$ Commonwealth ${ }^{28}$ on the basis of the level of international distress surrounding the 'red terror'. ${ }^{29}$

These apprehensions prompted Callinan and Heydon JJ to conclude that:

One solution...would be to reject the existence of "international concern" not reflected in treaties as a basis for $s 51$ (xxix) validity... There are immense difficulties facing any court wishing to recognise, as a matter of decision, the international concern doctrine. ${ }^{30}$

In any event, even if the concept was to apply, their Honours determined that it would not assist in establishing the validity of the relevant provisions which were directed at victims under 16 . This was because much of the international legislation used by the Commonwealth to demonstrate 'international concern' only applied to conduct directed at children under the age of 12 and was therefore narrower in its application than the relevant provisions of the Crimes Act 1914 (Cth). ${ }^{31}$

\section{'INTERNATIONAL CONCERN'32 - THE JOURNEY TO XYZ}

If on shaky ground after $X Y Z$, what has been the constitutional history of the concept of 'international concern' and how entrenched are its roots? Its history has been complicated. As Callinan and Heydon JJ observed, the concept 'potentially narrow[s] s 51(xxix) so far as it depends on treaties' but then 'is said to widen s 51(xxix) where no treaty can be relied on'.33

In the XYZ decision, Gummow, Hayne and Crennan JJ trace the phrase 'international concern' back to Willoughby's 1910 work, The Constitutional Law of the States. ${ }^{34}$ Certainly, the phrase had entered the High Court vernacular by the 1930 s with Latham CJ stating in $R v$ Burgess; Ex Parte Henry that '[n]o one would to-day be inclined to deny that the production and sale of recently invented narcotic drugs is a matter of international interest and concern'. 35

In Koowarta $v$ Bjelke-Petersen, ${ }^{36}$ Stephen $\mathrm{J}$, in considering the validity of the Racial Discrimination Act 1975 (Cth) (RDA) famously pronounced that '[a] subject-matter of international concern necessarily possesses the capacity to affect a country's relations with other nations and this quality is itself enough to make a subject-matter a part of a nation's "external affairs"'. ${ }^{37}$ He was of the view that the topic of racial discrimination

(1951) 83 CLR 1.

XYZ (2006) 227 ALR 495, 559 [222].

Ibid 560 [225].

Ibid 561 [226] (Callinan and Heydon JJ).

32 See generally Donald Rothwell, 'The High Court and the External Affairs Power: a Consideration of its Outer and Inner Limits' (1993) 15 Adelaide Law Review 209; See also Donald Rothwell, 'International Law and Legislative Power', in Brian Opeskin and Donald Rothwell (eds), International Lawe and Australian Federalism (1997) 104, 118-20.

33 XYZ (2006) 227 ALR 495, 557 [217].

34 Westel Willoughby, The Constitutional Law of the United States (1910) cited in XYZ (2006) 227 ALR 495, 510-11 [51]. Their Honours also cite an alternative view that the phrase might not have arisen until a 1929 speech given by Charles Evan Hughes: 510 [51].

35 (1936) 55 CLR 608, 640.

36 (1982) 153 CLR 168 ('Koowarta').

37 Ibid 217. 
had become a sufficient head of 'international concern' to enable the RDA to be within the external affairs power and that the existence of a treaty would not itself suffice. ${ }^{38}$

Mason J in that case was of the view that a 'matter' of 'external concern' could, by forming part 'of international debate, discussion and negotiation', come within s 51(xxix) even prior to the existence of a treaty. ${ }^{39}$ For Mason $\mathrm{J}$, the decision to enter into a treaty merely 'evidences the existence of international concern' ${ }^{40}$ Murphy J took a similar approach and did not think that the existence of a treaty was essential when the subject-matter constituted a matter of 'international concern', which on the facts could be found in 'the observance in Australia of international standards of human rights'. 41

The contrary view was expressed by Gibbs CJ, who was concerned that if s 51(xxix) applied upon ratification of a Convention or on the basis of 'international concern' the workings of federalism would be compromised. ${ }^{42}$

The concept of 'international concern' was further developed less than a decade later in Polyukhovich.43 The case saw Brennan and Toohey JJ discuss 'international concern' as an independent touchstone for the external affairs power while determining the constitutional validity of the War Crimes Act 1945 (Cth). The legislation targeted war crimes committed outside Australia during the Second World War and made such crimes offences under Australian law.

Brennan J recognised the inherently nebulous nature of 'international concern' and the reality that a 'multitude of topics' could come within its grasp by impacting on Australia's foreign relations even when they fell short of being unequivocal 'obligations' ${ }^{44}$ In seeking to limit the scope of the 'international concern' limb, Brennan J identified that:

unless standards are broadly adhered to or are likely to be broadly adhered to in international practice and unless those standards are expressed in terms which clearly state the expectation of the community of nations, the subject of those standards cannot be described as a true matter of international concern...It would be erroneous to attribute a scope to the external affairs power which depended on the broadest meaning which could be given to the imprecise phrase "international concern": that phrase is not a constitutional text... ${ }^{45}$

On this basis, his Honour concluded that there was insufficient 'international concern' at the time to bring the War Crimes Act 1945 (Cth) offence within the scope of the external affairs power. ${ }^{46}$ This conclusion was reached on the basis that

38 Ibid 216-19. Stephen J's reasons for upholding the RDA (one of these being on the basis of 'international concern') resulted in his alignment with the majority of Mason, Murphy \& Brennan JJ in accepting the constitutional validity of the legislation. Stephen J, however, took a narrower approach in not accepting the existence of an international convention as alone sufficient to attract the external affairs power. See XYZ (2006) 227 ALR 495, 556-7 [217] (Callinan and Heydon JJ).

39 Koowarta (1982) 153 CLR 168, 234.

$40 \quad$ Ibid 231.

41 Ibid 242.

42 Ibid 207.

43 (1991) 172 CLR 501.

$44 \quad$ Ibid 561.

45 Ibid 561-2.

46 Ibid 657-8 (Toohey J agreeing). 
international expectation did not extend to bringing people to trial in jurisdictions outside of those states in which the crimes were alleged to have been committed.

Further support for 'international concern' as an independent limb (as distinct from being considered an aspect of the treaty dimension of external affairs) can also be drawn from the majority judgments in the Tasmanian Dam Case. ${ }^{47}$ For Murphy J, even sufficient concern emerging within scientific circles might attract the external affairs label. ${ }^{48}$ His Honour also gave the example of concern internationally in relation to 'human rights violations' as 'often extend[ing] internal affairs to external affairs' ${ }^{49}$ Both Brennan $\mathrm{J}^{50}$ and Deane $\mathrm{J}^{51}$ referred to the pertinence of grounds such as 'international concern' in contexts in which binding obligations are not present. Deane J did however express the limitation that legislation must still be sufficiently proportionate. ${ }^{52}$

On the other hand, the concept of 'international concern' has resulted in significant 'divisions' on the bench. ${ }^{53}$ Mason J in the Tasmanian Dam Case stated that:

The fact that the power may extend to the subject matter of the treaty before it is made or adopted by Australia, because the subject matter has become a matter of international concern to Australia, does not mean that Parliament may depart from the provisions of the treaty after it has been entered into by Australia and enact legislation which goes beyond the treaty or is inconsistent with it. 54

Professor Rothwell later asserted that 'it cannot always be said...that international treaties truly represent existing international concern on certain subject matters' because of the compromises necessary to achieve unanimity. ${ }^{55}$ This dilemma is evident in the different view of Mason J in the Tasmanian Dam Case ${ }^{56}$ (set out above) to that later expressed by Dawson J in Richardson v Forestry Commission. ${ }^{57}$ Dawson J expressed doubt that, if 'international concern' was found to exist in relation to a topic, a treaty on a particular element of that topic should 'place outside the external affairs power that part of the subject matter which is beyond the limits of the treaty'.58 Moreover, his Honour was sceptical that legislation would not be stamped with the flavour of external affairs when it was previously within the domain of 'international concern' if a

47 (1983) 158 CLR 1, 131 (Mason J), 171-2, 174 (Murphy J), 258-9 (Deane J), 220 (Brennan J); cf 194 (Wilson J), 101-2 (Gibbs CJ), with Gibbs CJ requiring the topic to be seen 'as a proper subject for international action' of which the environment did not qualify when it was not 'such a burning international issue'.

Ibid.

50 Ibid 220.

51 Ibid 259.

52 Ibid.

53 XYZ (2006) 227 ALR 495, 560 [224] (Callinan and Heydon JJ).

54 Tasmanian Dam Case (1983) 159 CLR 1, 131-2; see XYZ (2006) 227 ALR 495, 560 [224] (Callinan and Heydon JJ); see also Leslie Zines, The High Court and the Constitution (3rd ed, 1997) 294 where Zines interpreted Mason J's comment as referring to the case where the topic of 'international concern' had, by virtue of a Convention, been 'negotiated to a conclusion'.

55 Rothwell, 'The High Court and the External Affairs Power: a Consideration of its Outer and Inner Limits', above n 32, 229; See also Rothwell, 'International Law and Legislative Power', above $\mathrm{n} 32,104,119-20$.

56 (1983) 159 CLR 1, 131-2.

57 (1988) 164 CLR 261, 325 ('Richardson').

58 Ibid. 
more tapered convention is later crafted on that subject. ${ }^{59}$ The position taken by Dawson J is consistent with his alignment with the minority in the Tasmanian Dam Case who followed Stephen J's approach in Koowarta, ${ }^{60}$ requiring 'international concern' rather than simply the existence of a treaty.

In Richardson Dawson J did indicate that the scope of 'international concern' was ever expanding and questioned whether some limits were necessary. ${ }^{61}$ His Honour once again expressed disquiet at the wide meaning of 'international concern' in Victoria $v$ Commonwealth. ${ }^{62}$ After citing Brennan J's statement in Polyukhovich set out above, ${ }^{63}$ Dawson J indicated that 'according to Brennan J...the only way in which international concern may ordinarily be established is by reference to standards which are obligatory or tantamount to obligatory in international law'. ${ }^{64}$ Dawson J suggested that with this unique construction of 'international concern', a Convention would 'provide the evidence, not only of international concern, but also of the extent of international concern'. ${ }^{65}$ He concluded that:

[t]he touchstone of the external affairs power should be externality, not international

concern. And if a law does exhibit the characteristic of externality, it should not matter

whether the law implements a treaty or not. ${ }^{66}$

The history of 'international concern' has been plagued both by the continuing expansion of the concept and the inherent difficulty in crafting clear guidelines for this aspect of the Commonwealth's external affairs power. Different judges have inconsistently looked to 'international concern' and, when they have done so, have adopted varied interpretations of the concept. Further, it is yet to be applied by a majority of the Court as the sole justification for the validity of a law within s 51(xxix). Many queries remain regarding the future of the concept. Can a piece of Commonwealth legislation cease to be supported by the external affairs power when its subject matter falls out of favour as a matter of 'international concern' and there is no other external affairs grounding? ${ }^{67}$ What is to be the role for 'international concern' within the external affairs power? Is it possible to define the concept of 'international concern' in a more meaningful way or does its past record require its abandonment?

\section{ARE WE BACK TO ABC AFTER XYZ?}

Following its chequered history and the most recent judicial statements in $X Y Z$ there is a real question as to whether the ship of 'international concern' is sinking fast without there being much commiseration at its demise. The issue is whether greater substance can be given to the 'international concern' concept to save it from its 'immense difficulties ${ }^{168}$ and repeatedly pronounced indeterminacy.

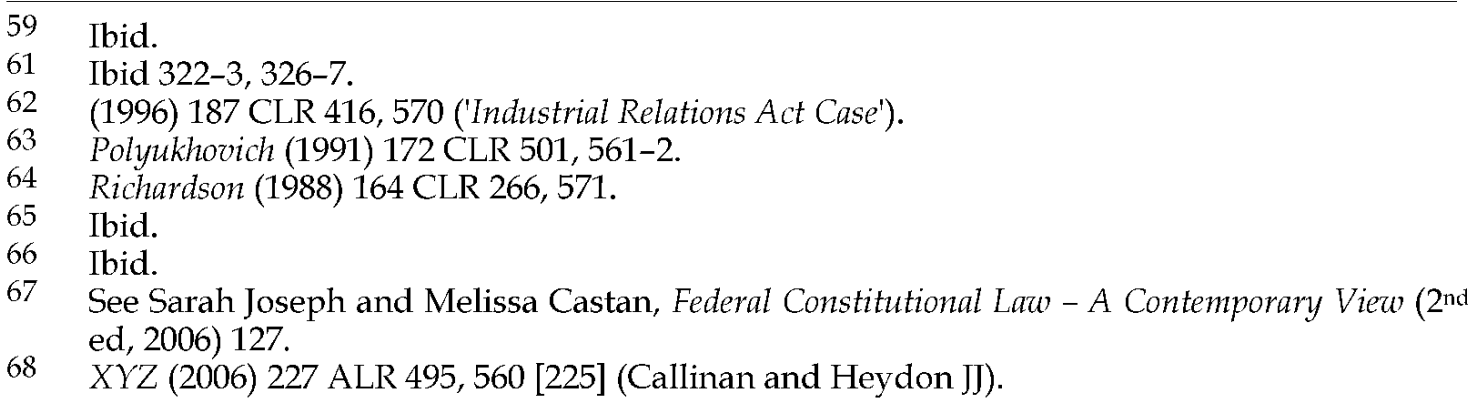


In $X Y Z$, Kirby $\mathrm{J}$ expressed unequivocally that, although some constitutional limits were essential, the Commonwealth Parliament should not have its wings clipped to such a degree that it is prevented from legislating, to the 'extent' possible for other countries, 'with respect to matters of international concern'. ${ }^{69}$ Although not needing to finally decide, his Honour emphasised that some parameters needed to be put in place for this 'undeveloped concept', 70 namely, that such a law must fall within the scope of s51(xxix), be consistent with the Commonwealth Constitution, as well as the federalist enterprise. ${ }^{71}$

The key questions which remain for the concept of 'international concern' are, firstly, is the concept productive? If so, what aspects need to be tweaked to address its 'undeveloped'72 nature?

Clearly, the concept of 'international concern' is not self-sufficient and has a role only within the external affairs sphere. ${ }^{73}$ Whether the concept is required depends primarily on the necessary scope of the Federal Parliament's legislative competence. ${ }^{74}$ In terms of its utility, Brennan J spoke in Polyukhovich ${ }^{75}$ of the Commonwealth Constitution assisting Australia 'to take its place among the nations of the world' and the need for the government to be able to pass legislation to comply:

with standards expected of and by the community of nations, even though those standards are not, or have not achieved the status of, obligations in international law. The observation of those standards may rightly be regarded as a matter of international concern...it is used to indicate that the power relates to matters affecting Australia's external relations even if those matters are not obligations under international law. ${ }^{76}$

When the scope of the external affairs power already seems to encompass areas such as treaty implementation, international recommendations and resolutions, geographical externality, relations with other countries and possibly customary international law, what work is left for the concept of 'international concern'? Frequently, there will be an overlap in the external affairs grounds used to support legislation, with 'international concern' often used as an auxiliary ground. ${ }^{77}$

Are there some issues that Australian citizens would expect the Commonwealth to address by legislation which would not fall under any limb other than 'international concern'? Does 'international concern' add a vital ingredient to the s51(xxix) pot? It is submitted that there is potentially work for 'international concern' to do within the external affairs head. ${ }^{78}$ It may give power to the Commonwealth to pass legislation to

XYZ (2006) 227 ALR 495, 529 [125] (Kirby J); see also 559 [221] (Callinan and Heydon JJ).

Ibid 530 [127](Kirby J).

Ibid 529 [125].

Ibid 530 [127].

Polyukhovich (1991) 172 CLR 501, 561-2.

XYZ (2006) 227 ALR 495, 502 [17] (Gleeson CJ).

Polyukhovich (1991) 172 CLR 501, 561.

Ibid 561-2.

See Tasmanian Dam Case (1983) 158 CLR 1,171 where Murphy J indicated that legislation said to be valid by virtue of s51(xxix) should 'be stated in terms of what is sufficient, even if categories overlap'. See also Brennan J in Polyukhovich (1991) 172 CLR 501, 561.

Of interest on this note is the dissenting view recently taken by McHugh $\mathrm{J}$ in Austin 0 Commonwealth (2003) 215 CLR 185, [224] where his Honour was reluctant to see the two Melbourne Corporation limbs collapsed into one on the basis that, although such a change may be of no consequence, '[i]f there is a difference... it may lead to unforeseen problems in 
address something of pressing international interest well before it crystallises as a binding obligation or international recommendation. ${ }^{79}$ From such issues may stem the expectation both at home and even overseas that the legislature acts pre-emptively. The environment is likely to be a source of 'international concern' when scientific advancements may mean that international obligations fail to keep step with 'burning international issue[s]'.80

How does 'international concern' compare with the 'relations with other countries' base? Is 'international concern' an unnecessary duplication following $R v$ Sharkey ${ }^{81}$ and Kirmani v Captain Cook Cruises Pty Ltd (No 1) ${ }^{82}$ Even if the 'relations with other countries' head were extended beyond relationships with other states to relationships with other international bodies such as the United Nations, ${ }^{83}$ there would still, it is suggested, be room for 'international concern'. ${ }^{84}$ It would simply depend on whether, in the first instance, the emphasis of the subject matter was on the international relationship or the issue itself. Admittedly, either starting point could potentially lead indirectly to, or have implications for, the other. This could be read into the comment made by Stephen J in Koowarta that international concern necessarily possesses the capacity to affect a country's relations with other nations' ${ }^{85}$ For example, legislation on the topic of extraordinary renditions, could, depending on the circumstances, form the subject of legislation either on the basis of a relevant bipartite state relationship or from the rendition debate generally. The latter debate is likely to impact upon international relationships but the relationship may not be sufficiently connected with the legislation at the outset. ${ }^{86}$ Alternatively, considerable international debate regarding greenhouse gas emissions may result in Commonwealth legislation introducing a carbon trading scheme. In the absence of binding obligations, this would be likely attract the 'international concern' label rather than instinctively align with the 'relations with other countries' limb, although international linkages and comparable schemes may still inform the methods adopted.

The problem is that 'international concern' has often been confusingly defined as feeding back into the 'relations with other countries' ground. ${ }^{87}$ This has meant that a topic is of 'international concern' if it has the potential to impact on Australia's international relations. It is submitted that this has impeded the ability of the concept to find a home for itself within the external affairs rubric. Certainly, Professor Zines has defined the 'relations with other countries' head as referring to laws which relate to

an area that is vague and difficult to apply. If there are no differences, no advantage is to be gained by jettisoning the formulation'.

Joseph and Castan, above n 67,127.

Tasmanian Dam Case (1983) 158 CLR 1,102 (Gibbs CJ).

(1949) 79 CLR 121 ('Sharkey').

(1985) 159 CLR 351 ('Kirmani').

Koowarta (1982) 153 CLR 168,258 (Brennan J); Tasmanian Dam Case (1983) 158 CLR 1,171 (Murphy J); XYZ (2006) 227 ALR 495, [134] (Kirby J).

84 Tasmanian Dam Case (1983) 158 CLR 1,171, where Murphy J applied the 'international concern' label to a hypothetical fear within scientific circles that something needed to be done internationally.

85 (1982) 153 CLR 168, 217.

86 See XYZ (2006) 227 ALR 495, 530-531 [129]-[132] (Kirby J).

87 See for example Koowarta (1982) 153 CLR 168, 217 (Stephen J); Tasmanian Dam Case (1983) 158 CLR 1,102 (Gibbs CJ), 194 (Wilson J), 220 (Brennan J). 
the 'subject' of 'relations between Australia and other governments'. 88 On this basis, 'international concern' can be distinguished from the 'relations with other countries' ground. Legislation on topics such as sedition, ${ }^{89}$ extradition $^{90}$ and foreign legislation ${ }^{91}$ could clearly then be differentiated from subjects which may affect international associations but do not themselves address overseas relations. ${ }^{92}$

A precise definition of 'international concern' seems to have eluded the courts. Even if it is determined that 'international concern' has some utility, the uncertainty of the concept has always been its greatest shortcoming. Its inherent elasticity has meant that it has been stretched and applied in such different ways that its usefulness is now being questioned.

If considered useful, it is vital that a more structured identity be adopted for 'international concern'. Potentially, Brennan J's approach in Polyukhovich ${ }^{93}$ could be the concept's saviour. ${ }^{94}$ His Honour referred to the importance of 'standards expected of and by the community of nations' which 'clearly state the expectation of the community of nations' and which are 'broadly adhered to in international practice'.95 For Brennan J these constitute non-negotiable elements for the 'subject of those standards' to be 'true matter[s] of international concern' ${ }^{196}$ 'even though those standards are not, or have not yet achieved the status of, obligations in international law' ${ }^{97}$

The approach of Brennan J, in seeking some level of predictability and specificity in the application of the concept of 'international concern' can, broadly, be paralleled with the procedural steps necessary to establish the formation of a rule of customary international law. ${ }^{98}$ On the facts of Polyukhovich, in the absence of an international 'obligation', there was a need for clear 'standards' and 'material' relating to the 'bringing to trial and punishment of war criminals' to establish the requisite 'international concern' to justify prosecution outside established 'international tribunals' or the countries directly affected .99

88

Zines, above n 54, 292-293; see also Sharkey (1949) 79 CLR 121, 136-7 (Latham CJ). Sharkey (1949) 79 CLR 121.

Vasiljkovic v Commonwealth (2006) 228 ALR 447.

Kirmani (1985) 159 CLR 351.

However, see Kirby J in XYZ (2006) 227 ALR 495, 532 [138] where his Honour takes a very broad approach in referring to the 'subject-matter' of the relevant provisions as being 'one relevant to the external relations of Australia with the international organisations concerned'. (1991) 172 CLR 501, 561-2.

See Industrial Relations Act Case (1996) 187 CLR 416,571 where Dawson J considered that Brennan J's approach diverged from other expositions of 'international concern'.

Polyukhovich (1991) 172 CLR 501, 561.

Ibid 561-2.

Ibid 561.

There is judicial support for matters within customary international law themselves falling within the scope of s 51(xxix) of the Commonwealth Constitution. See Tasmanian Dam Case (1983) 159 CLR 1, 258 (Deane J); Polyukhovich (1991) 172 CLR 501, 558 (Brennan J), 657 (Toohey J); Industrial Relations Act Case (1996) 187 CLR 416, 545 (Brennan CJ, Toohey, Gaudron, McHugh and Gummow JJ).

(1991) 172 CLR 501, 561-2. On the facts, Brennan J concluded that the evidence was 'insufficient...to show that the apprehension and trial of such war criminals before courts 
In a similar, though arguably more rigid way, the formation of customary international law generally requires a 'recurrence or repetition of the acts which give birth to the customary rule' as well as accompanying 'opinio juris sive necessitatis' which dictates the 'psychological aspect' whereby nations feel obligated to follow a particular rule which becomes a binding norm. ${ }^{100}$ It is this consistent and far-reaching practice of states $^{101}$ (such as from 'actual practice', 102 conventions, resolutions, legislation, NGOs ${ }^{103}$ ) and the accompanying subjective acceptance of the obligation which is decisive. However, as Shearer admits, the actual mechanics by which the formation of custom is tested is exceedingly complicated. ${ }^{104}$ This is compounded by what the International Court of Justice has recognised in a joint separate opinion as the 'conflicting and discordant practice of States'. ${ }^{105}$

Arguably, proving 'international concern' under Brennan J's method is less onerous than the process that is undertaken in establishing customary international law. The former would require 'standards' accompanied by a sufficient international 'expectation' as opposed to the requisite subjective belief in mandatory compliance required for 'opinio juris'. It is, however, feasible that something constituting 'international concern' under this approach may ultimately develop into custom as international expectation crystallises. ${ }^{106}$ Prior to this occurring, this analogous technique may help to delineate a more certain test for 'international concern'.

An attempt to adopt a more structured approach to the concept of international concern' would presumably require an extensive review of evidence that a subject had resulted in a sufficiently uniform approach being evident within an 'adequate' section of the international community along with an expectation of compliance. On the facts of $X Y Z$, the Commonwealth's evidence concerning action taken internationally in relation to sexual crimes against children (of a certain age) would presumably be presented along with statements from the international community as to the

of countries other than those in which the crimes were committed were ever matters of international concern'.

Ivan Shearer, Starke's International Law (11'th ed, 1994) 33-34; North Sea Continental Shelf (Judgment) [1969] ICJ Rep 44,[77]; Military and Paramilitary Activities in and against Nicaragua (Nicaragua v the United States of America),(Merits)(Judgment) [1986] ICJ Rep 108-109, ('Nicaragua Case') [207]. See also Stephen J in Koowarta (1982) 153 CLR 168, 220 where his Honour was of the view that 'non-discrimination on the grounds of race, is now part of customary international law'.

101 Although as recognised in Nicaragua Case (Merits)(Judgment) [1986] ICJ Rep 98, [186], completely flawless evidence of practice is not essential; see also Michael Akehurst, 'Custom as a Source of International Law' in Martti Koskenniemi (ed), Sources of International Law (2000) 251, 264, 266.

102 Continental Shelf (Libyan Arab Jamahiriya/Malta) (Judgment) [1985] ICJ Rep 31-32, [29-30].

103 Akehurst, above n 101, 251; Rebecca Wallace, International Law (5th ed, 2005) 15.

104 Shearer, above n 100, 36. See also Anthony D'Amato, 'Trashing Customary International Law' (1987) 81 American Journal of International Law 101 and Gillian Trigg, International Law Contemporary Principles and Practices (2006) 45 who refers to customary international law as often 'proving unpredictable and variable' and as being 'ill-suited to resolv[ing] contemporary international legal problems' in the face of 'multilateral treaties'. As to the need for greater clarity see G.M Danilenko, Law-Making in the International Community (1993) 128. 
importance placed on adhering to a policy of zero tolerance in relation to such offences so as to demonstrate 'international concern'. However, the difficulty posed in collating the necessary evidence is likely to remain a very real obstacle to any further refinement of the 'international concern' limb. ${ }^{107}$ Particularly after $X Y Z,{ }^{108}$ the difficulty identified by Professor Rothwell is in knowing how high the evidentiary bar is placed. ${ }^{109}$ Would the involvement of established international organisations be a prerequisite to ignite an international debate or would a bilateral statement suffice? ${ }^{110}$

It is submitted that, in spite of some evidentiary obstacles, the touchstone postulated by Brennan J could go some way to remedying the historically equivocal nature of 'international concern'. However, even if its fluidity is addressed, the concept can only be redeemed if it comes to fill a niche within the external affairs power beyond that of a mere overlapping ground. The $X Y Z$ case has only confirmed the breadth of the 'geographical externality' aspect. When this is combined with the other external affairs limbs there needs to be a reason to retain 'international concern'. This paper has submitted that there is a role for 'international concern' and that it remains to be seen whether this is played out in the future.

\section{CONCLUSION}

The High Court in $X Y Z$ seriously questioned, in obiter dicta, the role of 'international concern' when assessing the constitutionality of Commonwealth legislation claimed to be with respect to external affairs. Potentially, an approach roughly akin to that used by international jurists in respect of custom might go some way to remedying the chronic uncertainty plaguing the application of 'international concern'. However, even the imposition of such a process would not necessarily be a panacea. A more secure foundation will not arise for 'international concern' until the Court settles upon its primary function. After $X Y Z$ one thing seems indisputable: if the Commonwealth seeks to rely solely on the concept of 'international concern' to support a s 51(xxix) law it will face an arduous battle next time the bench is called upon to consider that criterion squarely on its merits.

See especially XYZ (2006) 227 ALR 495, 558 [219] (Callinan and Heydon JJ).

Ibid 503 [19] where Gleeson CJ thought it dubious that airing at an international form would suffice to render something of 'international concern'; see also 558 [219] (Callinan and Heydon JJ).

Rothwell, 'The High Court and the External Affairs Power: a Consideration of its Outer and Inner Limits', above n 32, 229-30.

Ibid; see also Geoffrey Sawer, 'The External Affairs Power' (1984) 14 Federal Law Review 199. 